\title{
Identifikasi Kesalahan Mahasiswa Dalam Menyelesaikan Masalah Matematika (Studi Kasus Masalah Segitiga Pada Mata Kuliah Trigonometri)
}

\author{
Yayan Eryk Setiawan \\ Program Studi Pendidikan Matematika, FKIP, Universitas Islam Malang \\ *Corresponding Author. Email: yayaneryksetiawan@unisma.ac.id
}

\begin{abstract}
This study aims to describe mistakes made by first-semester students in solving triangle problems in trigonometry subjects. This research was a qualitative descriptive study with a case study approach. The subjects of this study were students of the first semester of the mathematics education study program at a tertiary institution in the city of Malang. The research instrument consisted of a question about solving triangular problems in the context of trigonometry and an interview guide. The data collected in this study consisted of the results of the subjects' works and transcripts of interview results. Subject work data were analyzed descriptively to determine the type of error made by the subjects. The transcript data from the interview results were analyzed using coding which aimed to determine the factors causing the subjects' errors. The results showed that the errors of 19 students in solving triangular problems in the context of trigonometry obtained $39 \%$ on concept errors, $28 \%$ on principle errors, $6 \%$ on miscalculations, and $33 \%$ on factual errors.
\end{abstract}

\begin{abstract}
Abstrak: Tujuan penelitian ini adalah untuk mendeskripsikan kesalahankesalahan yang dilakukan oleh mahasiswa semester pertama dalam menyelesaikan masalah segitiga pada mata kuliah trigonometri. Metode penelitian ini adalah penelitian deskriptif kualitatif dengan pendekatan studi kasus. Subjek penelitian ini adalah mahasiswa semester pertama program studi pendidikan matematika di salah satu perguruan tinggi di Kota Malang. Instrumen penelitian ini terdiri dari satu soal tentang pemecahan masalah segitiga dalam konteks trigonometri dan pedoman wawancara. Data yang dikumpulkan dalam penelitian ini terdiri dari hasil pekerjaan subjek dan transkrip hasil wawancara. Data hasil pekerjaan subjek dianalisis secara deskriptif untuk mengetahui jenis kesalahan subjek. Data transkrip hasil wawancara dianalisis dengan pengkodean yang bertujuan untuk mengetahui faktor-faktor penyebab kesalahan subjek. Hasil penelitian menunjukkan bahwa kesalahan dari 19 mahasiswa dalam dalam menyelesaikan masalah segitiga pada konteks trigonometri diperoleh 39\% mengalami kesalahan konsep, 28\% mengalami kesalahan prinsip, 6\% mengalami kesalahan hitung, dan $33 \%$ mengalami kesalahan fakta.
\end{abstract}

\section{Article History}

Received: 04-01-2021

Revised: 17-03-2021

Accepted: 23-05-2021

Published: 07-09-2021

\section{Key Words:}

Trigonometry, Concept

Errors, Principle Errors, Miscalculations, Factual Errors.

\section{Sejarah Artikel}

Diterima: 04-01-2021

Direvisi: 17-03-2021

Disetujui: 23-05-2021

Diterbitkan: 07-09-2021

\section{Kata Kunci:}

Trigonometri, Kesalahan Konsep, Kesalahan Prinsip, Kesalahan Hitung, Kesalahan Fakta.

How to Cite: Setiawan, Y. (2021). Identifikasi Kesalahan Mahasiswa Dalam Menyelesaikan Masalah Matematika (Studi Kasus Masalah Segitiga Pada Mata Kuliah Trigonometri). Jurnal Kependidikan: Jurnal Hasil Penelitian dan Kajian Kepustakaan di Bidang Pendidikan, Pengajaran dan Pembelajaran, 7(3), 649-662. doi:https://doi.org/10.33394/jk.v7i3.3329

https://doi.org/10.33394/jk.v7i3.3329

This is an open-access article under the CC-BY-SA License.

\section{Pendahuluan}

Trigonometri merupakan cabang ilmu matematika yang secara umum membahas mengenai segitiga dan secara khusus membahas mengenai fungsi trigonometri (Downing, 2009; Lial, Hornsby, Schneider, \& Daniels, 2016). Sebagian perguruan tinggi membelajarkan Trigonometri sebagai salah satu mata kuliah yang harus di tempuh oleh mahasiswa program studi pendidikan matematika. Pentingnya mata kuliah trigonometri untuk ditempuh oleh 
mahasiswa program studi pendidikan matematika dikarenakan materi trigonometri dibelajarkan pada jenjang sekolah menengah atas. Oleh karena itu, sebagai calon guru, maka mahasiswa program studi pendidikan matematika harus menguasai konsep-konsep yang ada dalam mata kuliah trigonometri. Selain itu, mata kuliah trigonometri ini juga merupakan mata kuliah prasyarat untuk mata kuliah kalkulus, analisis vektor, dan persamaan diferensial.

Salah satu materi yang dipelajari dalam mata kuliah trigonometri adalah pemecahan masalah segitiga. Pemecahan masalah segitiga dalam konteks trigonometri memiliki arti menemukan semua ukuran panjang sisi dan besar sudut pada segitiga (Lial et al., 2016). Secara khusus pemecahan masalah segitiga pada konteks trigonometri ini merupakan penerapan dari materi perbandingan trigonometri pada segitiga siku-siku. Contoh pemecahan masalah segitiga dapat dilihat dalam Gambar 1 (dibawah). Dari Gambar 1 dapat dilihat bahwa pemecahan masalah segitiga pada konteks trigonometri berarti menemukan besar sudut-sudut yang belum diketahui, serta menemukan panjang sisi $a, b, c$, dan $d$. Materi pemecahan masalah segitiga ini penting untuk dipelajari oleh mahasiswa yang menempuh mata kuliah trigonometri. Hal ini dikarenakan pemahaman konsep tentang perbandingan fungsi trigonometri segitiga dapat diketahui dari kemampuannya untuk menyelesaikan masalah segitiga. Berbagai hasil penelitian menjelaskan bahwa salah satu indikator seseorang menguasai suatu konsep adalah dapat menerapkan konsep tersebut untuk menyelesaikan suatu masalah (Setiawan, 2020; Setiawan \& Mustangin, 2020b, 2020a; Setiawan \& Syaifuddin, 2020).

Akan tetapi hasil studi pendahuluan terhadap 82 mahasiswa program studi pendidikan matematika di salah satu perguruan tinggi di Kota Malang menunjukkan bahwa 57 mahasiswa menjawab benar dan 25 mahasiswa menjawab salah. Ini artinya terdapat 30\% mahasiswa yang mengalami kesalahan dalam memecahkan masalah segitiga pada materi trigonometri. Kesalahan-kesalahan mahasiswa ini penting untuk dianalisis lebih lanjut untuk mengetahui kesalahpahaman mahasiswa dalam memecahkan masalah segitiga. Pentingnya analisis kesalahan ini dikarenakan dengan teridentifikasinya kesalahan-kesalahan mahasiswa, maka mahasiswa dapat memperbaiki kesalahpahamnnya (Ball, 1993; Ball \& Friel, 1991; Borasi, 1994; Kazemi, 1998) dan guru atau dosen dapat memperbaiki pembelajarannya untuk memperbaiki kesalahpahaman siswa atau mahasiswa (Schleppenbach, Flevares, \& Sims, 2007; Setiawan, 2020b, 2020c; Webb \& Mastergeorge, 2003).

Penelitian tentang kesalahan mahasiswa dalam menyelesaikan masalah trigonometri menjadi perhatian beberapa peneliti. Penelitian Jaelani (2017) menganalisis tentang kesalahan mahasiswa semester pertama dalam menyelesaikan masalah trigonometri yang menunjukkan bahwa mahasiswa semester pertama mengalami kesalahan rumus dalam menyelesaikan masalah trigonometri. Penelitian Imelda (2018) menganalisis kesulitan mahasiswa dalam memecahkan masalah aljabar dan trigonometri yang menunjukkan bahwa mahasiswa kesulitan dalam menyelesaikan persamaan trigonometri yang dikarenakan mahasiswa kurang menguasai konsep dan prinsip trigonometri. Penelitian lain menganalisis persepsi mahasiswa calon guru terhadap mata kuliah trigonometri yang menunjukkan bahwa mata kuliah trigonometri dianggap sulit, abstrak, dan membosankan (Nabie, Akayuure, Ibrahim-Bariham, \& Sofo, 2018). Hasil penelitian juga menunjukkan bahwa mahasiswa mengalami kesalahan konseptual, kesalahan prosedural, dan kesalahan faktual dalam menyelesaikan masalah trigonometri (Hidayat \& Aripin, 2020), serta mengalami kesalahan hitung, kesalahan fakta, dan kesalahan prinsip (Setiawan, 2021a, 2021b) Akan tetapi penelitian yang telah dilakukan sebelumnya ini tidak membahas mengenai pemecahan masalah segitiga pada konteks trigonometri. Oleh karena itu, masih diperlukan penelitian untuk menganalisis kesalahan mahasiswa dalam menyelesaikan masalah segitiga pada konteks trigonometri. 
Berbeda dengan penelitian yang telah dilakukan oleh beberapa peneliti (Hidayat \& Aripin, 2020; Imelda, 2018; Jaelani, 2017; Nabie et al., 2018; Setiawan, 2021a; 2021b), penelitian ini bertujuan untuk mendeskripsikan kesalahan-kesalahan yang dilakukan oleh mahasiswa semester pertama dalam menyelesaikan masalah segitiga pada mata kuliah trigonometri beserta faktor-faktor penyebabnya. Adapun manfaat teoritis dari penelitian ini adalah menghasilkan teori kesalahan dalam materi pemecahan masalah segitiga pada mata kuliah trigonometri. Sedangkan manfaat praktis dari hasil penelitian ini adalah dapat digunakan oleh mahasiswa untuk memperbaiki pemahamannya dalam menyelesaikan masalah segitiga serta dapat digunakan oleh dosen atau guru untuk memperbaiki pembelajaran yang dilakukan di kelas, khususnya pada materi pemecahan masalah segitiga.

\section{Metode Penelitian}

Metode penelitian ini menggunakan penelitian deskriptif kualitatif dengan pendekatan studi kasus. Penelitian ini dilaksanakan di Universitas Islam Malang pada semester ganjil tahun akademik 2020/2021. Prosedur pemilihan subjek dalam penelitian ini dilaksanakan dalam tiga langkah. Langkah pertama adalah meminta 82 mahasiswa program studi pendidikan matematika pada semester pertama untuk menyelesaikan soal pemecahan masalah segitiga dalam konteks trigonometri (lihat Gambar 1). Langkah kedua mengoreksi jawaban mahasiswa berdasarkan jawaban benar dan salah, sehingga diperoleh 57 menjawab benar dan 25 menjawab salah. Langkah ketiga adalah menglasifikasikan jawaban salah berdasarkan jenis-jenis kesalahan (lihat Tabel 1), sehingga diperoleh 5 karakteristik kesalahan yang berbeda. Dari 5 karakteristik kesalahan tersebut dipilih 1 mahasiswa sebagai subjek penelitian untuk dianalisis lebih lanjut, sehingga diperoleh subjek penelitian ini sebanyak 5 mahasiswa.

Data yang dikumpulkan dalam penelitian ini terdiri dari hasil pekerjaan subjek dan transkrip hasil wawancara dengan subjek. Prosedur pengumpulan data hasil pekerjaan subjek dilakukan sesuai dengan langkah-langkah pemilihan subjek. Prosedur pengumpulan data transkrip hasil wawancara dilakukan dengan dua langkah. Langkah pertama adalah melakukan wawancara dengan subjek penelitian melalui media whatsapp. Langkah kedua adalah mentranskrip kata demi kata dari hasil wawancara, sehingga diperoleh transkrip hasil wawancara dengan subjek penelitian.

Instrumen penelitian ini terdiri dari satu soal tes tentang pemecahan masalah segitiga pada mata kuliah trigonometri (lihat Gambar 1) dan pedoman wawancara yang dikembangkan oleh peneliti sendiri. Dari Gambar 1 dapat dilihat bahwa instrumen penelitian dapat digunakan untuk mengetahui kesalahan yang dilakukan oleh mahasiswa dalam menyelesaikan masalah segitiga. Hal dikarenakan jika mahasiswa salah dalam memahami konsep-konsep (yaitu definisi fungsi trigonometri segitiga, aturan sin pada segitiga, teorema pythagoras, dan konsep kesetaraan) yang dapat digunakan untuk menyelesaikan masalah segitiga, maka mahasiswa akan mengalami kesalahan konsep. Jika mahasiswa salah dalam menerapkan konsep yang sudah dipahami, maka mahasiswa akan terjebak dalam kesalahan prinsip. Penyelesaian soal juga melibatkan operasi hitung. Jika mahasiswa melakukan kesalahan dalam menentukan hasil operasi hitung, maka mahasiswa mengalami kesalahan hitung. Pada soal juga memuat informasi. Jika mahasiswa salah dalam mengidentifikasi informasi yang ada dalam soal, maka mahasiswa mengalami kesalahan fakta. Jadi instrumen penelitian ini valid digunakan untuk mengidentifikasi kesalahan-kesalahan mahasiswa dalam menyelesaikan masalah segitiga pada konteks trigonometri.

Analisis data hasil pekerjaan mahasiswa dilakukan dengan menglasifikasikan berdasarkan kesalahan konsep, kesalahan prinsip, kesalahan hitung, dan kesalahan fakta (lihat Tabel 1). Alasan menglasifikasikan kesalahan mahasiswa dalam memecahkan masalah 
segitiga dikarenakan pemecahan masalah segitiga ini melibatkan konsep perbandingan trigonometri, aturan sin pada segitiga, teorema Pythagoras dan konsep kesetaraan. Jika mahasiswa mahasiswa salah dalam memahami ketiga konsep ini, maka termasuk kategori kesalahan konsep. Kesalahan konsep didefinisikan sebagai kesalahan dalam memahami suatu konsep (Setiawan, 2020). Jika mahasiswa sudah memahami konsep, tetapi mahasiswa salah dalam menerapkan konsep tersebut, maka termasuk kategori kesalahan prinsip. Kesalahan prinsip didefinisikan sebagai kesalahan menerapkan aturan, teorema, definisi, atau sifat dalam menyelesaikan masalah matematika (Setiawan, 2020). Selanjutnya jika mahasiswa salah dalam menentukan hasil operasi hitung, maka termasuk kategori kesahan hitung. Jika mahasiswa salah dalam mengidentifikasi informasi yang ada dalam soal, maka termasuk kesalahan fakta. Jadi dapat dikatakan bahwa klasifikasi kesalahan konsep, kesalahan prinsip, kesalahan hitung, dan kesalahan fakta telah sesuai dengan instrumen penelitian yang digunakan.

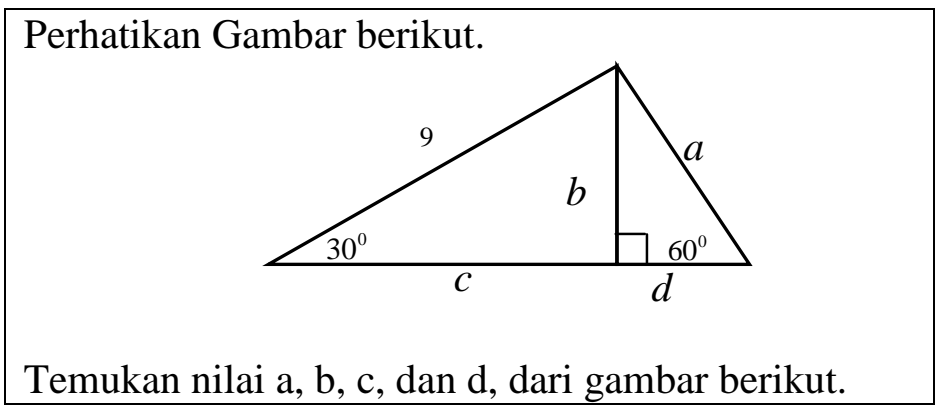

\section{Gambar 1. Instrumen Penelitian}

Selanjutnya untuk analisis data transkrip hasil wawancara dilakukan dengan pengkodean. Setiap kata dikodekan untuk mengetahui faktor-faktor yang menyebabkan subjek melakukan kesalahan dalam memecahkan masalah segitiga. Melalui analisis hasil pekerjaan dan transkrip wawancara ini, maka akan diperoleh deskripsi kesalahan-kesalahan mahasiswa dalam menyelesaikan masalah segitiga dalam konteks trigonometri beserta faktorfaktor penyebabnya.

\section{Tabel 1. Kerangka Klasifikasi Kesalahan Mahasiswa}

\begin{tabular}{ll}
\hline \multicolumn{1}{c}{ Jenis Kesalahan } & \multicolumn{1}{c}{ Indikator-indikator } \\
\hline Kesalahan Konsep & $\begin{array}{l}\text { Kesalahan dalam memahami konsep-konsep (yaitu definisi } \\
\text { trigonometri segitiga, aturan sin pada segitiga, teorema } \\
\text { pythagoras, dan konsep kesetaraan) yang digunakan untuk } \\
\text { menyelesaikan masalah segitiga. }\end{array}$ \\
\hline Kesalahan Prinsip & $\begin{array}{l}\text { Kesalahan dalam menerapkan konsep-konsep yang } \\
\text { digunakan untuk menyelesaikan masalah segitiga. }\end{array}$ \\
\hline Kesalahan Hitung & Kesalahan dalam melakukan perhitungan. \\
\hline Kesalahan Fakta & $\begin{array}{l}\text { Kesalahan dalam mengidentifikasi informasi yang ada dalam } \\
\text { soal. }\end{array}$ \\
\hline
\end{tabular}

\section{Hasil Penelitian dan Pembahasan}

Hasil penelitian menunjukkan bahwa dari 82 mahasiswa yang menjawab soal tentang pemecahan masalah segitiga pada konteks trigonometri diperoleh 25 mahasiswa menjawab salah. Dari 25 mahasiswa tersebut diperoleh 3 mahasiswa tidak menjawab karena kesulitan, 3 mahasiswa belum selesai dalam menjawab karena waktu mengerjakan soal telah habis, dan 19 mahasiswa menjawab salah. Hasil klasifikasi kesalahan dari 19 mahasiswa tersebut dapat dilihat dalam Tabel 2. 


\section{Tabel 2. Hasil Klasifikasi Kesalahan Mahasiswa dalam Menyelesaikan Masalah Segitiga}

\begin{tabular}{lllc}
\hline $\begin{array}{c}\text { Jenis } \\
\text { Kesalahan }\end{array}$ & \multicolumn{1}{c}{$\begin{array}{c}\text { Indikator-Indikator } \\
\text { Kesalahan }\end{array}$} & \multicolumn{1}{c}{$\begin{array}{c}\text { Kesalahan dalam Memecahkan } \\
\text { Masalah Segitiga }\end{array}$} & $\begin{array}{c}\text { Banyak } \\
\text { Mahasiswa }\end{array}$ \\
\hline $\begin{array}{l}\text { Kesalahan } \\
\text { Konsep }\end{array}$ & $\begin{array}{l}\text { Kesalahan dalam } \\
\text { memahami konsep-konsep } \\
\text { yang berkaitan dengan } \\
\text { masalah segitiga }\end{array}$ & $\begin{array}{l}\text { Kesalahan memahami perbandingan } \\
\text { trigonometri untuk menyelesaikan } \\
\text { masalah segitiga. }\end{array}$ & 7 \\
\hline $\begin{array}{l}\text { Kesalahan } \\
\text { prinsip }\end{array}$ & $\begin{array}{l}\text { Kesalahan dalam } \\
\text { menerapkan konsep atau } \\
\text { aturan untuk } \\
\text { menyelesaikan masalah } \\
\text { segitiga }\end{array}$ & $\begin{array}{l}\text { Kesalahan menerapkan perbandingan } \\
\text { trigonometri segitiga untuk } \\
\text { menyelesaikan masalah segitiga }\end{array}$ & $\begin{array}{l}\text { Kesalahan dalam menentukan nilai } \\
\text { fungsi trigonometri. }\end{array}$ \\
\hline $\begin{array}{l}\text { Kesalahan } \\
\text { hitung }\end{array}$ & $\begin{array}{l}\text { Kesalahan dalam } \\
\text { menentukan hasil operasi } \\
\text { hitung }\end{array}$ & $\begin{array}{l}\text { Kesalahan dalam menentukan hasil } \\
\text { operasi hitung yang melibatkan bentuk } \\
\text { ekuivalensi bilangan. }\end{array}$ & 1 \\
\hline $\begin{array}{l}\text { Kesalahan } \\
\text { fakta }\end{array}$ & $\begin{array}{l}\text { Kesalahan dalam } \\
\text { mengidentifikasi informasi }\end{array}$ & $\begin{array}{l}\text { Kesalahan tidak memperhatikan } \\
\text { panjang sisi yang diketahui untuk } \\
\text { mencari panjang sisi yang ditanyakan. }\end{array}$ & 1 \\
\hline yang ada dalam soal & Total & 19 \\
\hline
\end{tabular}

Pada Tabel 2 dapat dilihat bahwa dari 19 mahasiswa yang mengalami kesalahan dalam menyelesaikan masalah segitiga diperoleh 39\% mengalami kesalahan konsep, $28 \%$ mengalami kesalahan prinsip, 6\% mengalami kesalahan hitung, dan 33\% mengalami kesalahan fakta. Selanjutnya dari masing-masing kesalahan diambil 1 mahasiswa dijadikan subjek penelitian untuk dianalisis lebih lanjut mengenai kesalahan dan faktor penyebabnya, sehingga diperoleh 5 subjek penelitian. Hasil analisis dari 5 subjek penelitian ini dipaparkan sebagai berikut.

\section{Kesalahan Konsep}

Kesalahan konsep yang muncul dalam penelitian ini adalah kesalahan dalam memahami perbandingan trigonometri untuk menyelesaikan masalah segitiga. Dari 7 mahasiswa yang mengalami kesalahan ini dipilih satu mahasiswa sebagai subjek pertama (S1) dalam penelitian ini. Hasil pekerjaan subjek pertama dapat dilihat dalam Gambar 2.

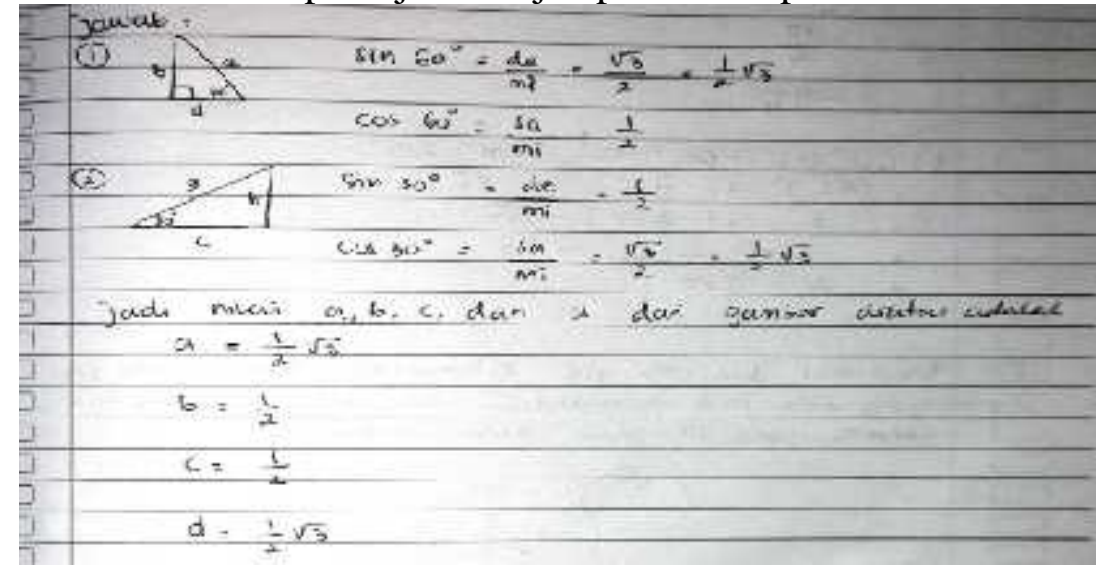

\section{Gambar 2. Kesalahpahaman Terhadap Perbandingan Trigonometri}

Dari Gambar 2 dapat dilihat bahwa kesalahpahaman mahasiswa adalah secara langsung menentukan nilai sisi-sisi segitiga dengan menggunakan nilai fungsi trigonometri tanpa melihat perbandingan yang sesuai. Faktor penyebab kesalahan ini dapat diketahui dari cuplikan wawancara berikut. 
$P \quad: \quad J e l a s k a n$ bagaimana Anda memperoleh jawaban tersebut?

S1 : ... Sin 60 derajatnya sama dengan setengah akar tiga. .... saya menyimpulkannya bahwa nilai a adalah setengah akar tiga yang diperoleh dari sin 60 derajat ini.

Kemudian nilai b nya diperoleh dari cos 60 derajat. Kemudian untuk nilai c nya ini kita peroleh dari sin 30 derajat, jadi kan depan per miring sama dengan 1 per 2. Jadi sin 30 derajat sama dengan setengah adalah nilai c. kemudian untuk nilai d nya saya menyimpulkannya yaitu dari cos 30 derajat ....

Dari cuplikan hasil wawancara dapat diketahui bahwa kesalahpahaman subjek yaitu memahami apabila salah satu sisi dari perbandingan trigonometri sudah diketahui, maka nilai fungsi trigonometri tersebut adalah panjang sisi yang lainnya. Misalnya subjek mengatakan bahwa panjang $b=\frac{1}{2}$ dikarenakan $\sin 30^{\circ}=\frac{\text { depan }}{\text { miring }}=\frac{1}{2}$, dimana sisi depan adalah $b$ dan sisi miring adalah 9. Jadi dapat dikatakan bahwa faktor penyebab kesalahan dalam memahami perbandingan trigonometri untuk menyelesaikan masalah segitiga adalah kesalahpahaman terhadap perbandingan yang melibatkan panjang sisi yang diketahui dengan panjang sisi yang ditanyakan.

\section{Kesalahan Prinsip}

Kesalahan prinsip yang pertama adalah kesalahan dalam menerapkan definisi perbandingan trigonometri pada segitiga. Dari 4 mahasiswa yang mengalami kesalahan ini, dipilih 1 mahasiswa sebagai subjek kedua (S2) dalam penelitian ini. Hasil pekerjaan subjek kedua dapat dilihat dalam Gambar 3.

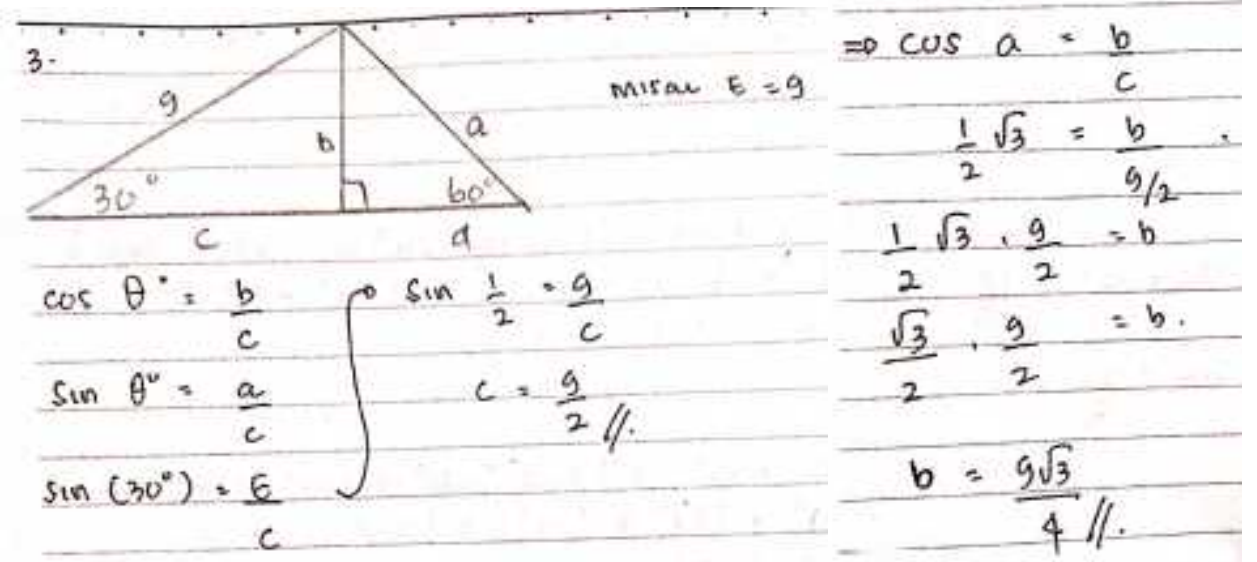

\section{Gambar 3. Kesalahpahaman Menerapkan Perbandingan Trigonometri Segitiga}

Dari Gambar 3 dapat dilihat bahwa subjek melakukan kesalahan dalam menerapkan perbandingan trigonometri segitiga, dimana kesalahan subjek menuliskan cos adalah $b$ per $c$, sin adalah $a$ per $c$, dan sin 30 derajat adalah 9 per $c$. Akibatnya subjek salah dalam menentukan nilai $a, b, c$, dan $d$. Faktor penyebab kesalahan ini dapat diketahui dari cuplikan transkrip hasil wawancara berikut.

$P \quad:$ Jelaskan bagaimana Anda memperoleh jawaban tersebut?

$S 2$ : Saya menggunakan rumus dari perbandingan trigonometri dari suatu segitiga, yaitu demi, sami, desa, mide, misa, dan sade. Disini saya memisalkan e sama dengan 9. Karena yang ditanya nilai $a, b, c$, dan d, maka dengan menggunakan cara tersebut lebih gampang bagi saya untuk mengerjakannya.

Dari cuplikan hasil wawancara dapat diketahui bahwa subjek sudah memahami perbandingan trigonometri segitiga, yaitu sindemi, cosami, dan tandesa. Akan tetapi yang diingat oleh subjek adalah sisi depan adalah sisi $a$, sisi samping adalah sisi $b$, dan sisi miring adalah sisi $c$ tanpa memperhatikan letak $a, b$, dan $c$ pada gambar. Akibatnya subjek salah dalam 
menentukan nilai $a, b, c$, dan $d$, karena penerapan perbandingan trigonometri tidak memperhatikan letak dari sisi depan, sisi mirng, dan sisi samping. Jadi dapat dikatakan bahwa faktor yang menyebabkan kesalahan subjek dalam menerapkan perbandingan trigonometri segitiga adalah tidak memperhatikan sisi depan, sisi samping, dan sisi miring dari sudut yang diketahui (yang hanya menghafal perbandingan trigonometri segitiga saja).

Kesalahan prinsip yang kedua adalah kesalahan dalam menentukan nilai fungsi trigonometri. Terdapat 1 mahasiswa yang mengalami kesalahan ini dan dipilih sebagai subjek ketiga (S3). Hasil pekerjaan dari subjek ketiga ini dapat dilihat dalam Gambar 4.

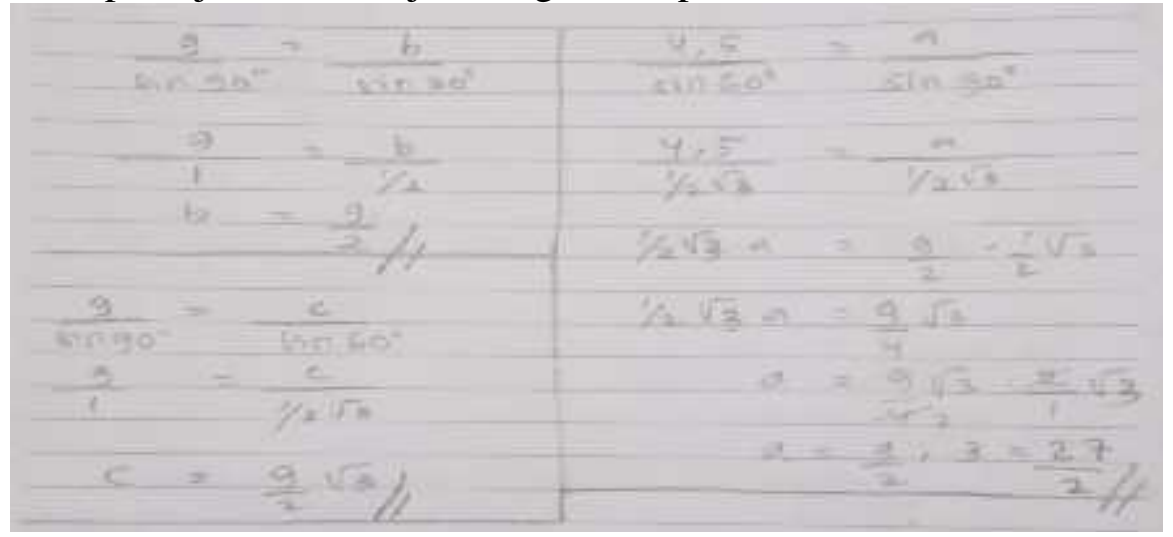

Gambar 4. Kesalahan Menentukan Nilai Fungsi Trigonometri

Dari Gambar 4 dapat dilihat bahwa subjek salah dalam menentukan nilai dari sin 90 derajat, dimana subjek menentukan sin 90 derajat adalah setengah akar tiga. Faktor penyebab kesalahan subjek ini dapat diketahui dari cuplikan wawancara berikut ini.

$P \quad:$ Mengapa Anda menuliskan sin 90 derajat sama dengan setengah akar tiga?

S3 : Maaf pak, saya salah itu, karena saya kurang teliti.

Dari cuplikan hasil wawancara dapat diketahui bahwa faktor penyebab subjek mengalami kesalahan dalam menentukan nilai fungsi trigonometri adalah kurang teliti. Oleh karena itu subjek mengalami kesalahan dalam menentukan nilai sin 90 derajat.

Kesalahan Hitung

Terdapat 1 mahasiswa yang mengalami kesalahan hitung dalam menerapkan konsep ekuivalensi dari bilangan. Selanjutnya satu mahasiswa ini dipilih sebagai subjek keempat (S4) penelitian ini. Hasil pekerjaan subjek keempat dapat dilihat dalam Gambar 5. Dari Gambar 5 dapat dilihat bahwa subjek mengalami kesalahan dalam menerapkan konsep kesetaraan. Faktor penyebab kesalahan subjek dalam menerapkan konsep kesetaraan dapat diketahui dari cuplikan transkrip wawancara berikut.

$P \quad:$ Mengapa Anda menuliskan b sama dengan setengah dibagi 9?

S4 : Karena b dibagi 9 pak, jadi untuk mencari nilai b adalah setengah juga dibagi 9.

Dari cuplikan transkrip hasil wawancara dapat diketahui bahwa faktor yang menyebabkan subjek mengalami kesalahan dalam menerapkan konsep kesetaraan adalah pemahaman yang salah dalam menentukan bilangan dari bentuk ekuivalensi perbandingan bilangan. Kesalahpahaman subjek adalah mengira bahwa jika bilangan yang dicari (yaitu $b$ ) dibagi dengan bilangan tertentu (yaitu 9), maka untuk mencari nilai $b$ dilakukan dengan membagi bilangan yang ekuivalen (yaitu 1/2) dengan pembagi bilangan yang dicari (yaitu 9). Kesalahan ini termasuk kesalahpahaman dalam menentukan hasil operasi yang melibatkan bentuk ekuivalensi. 


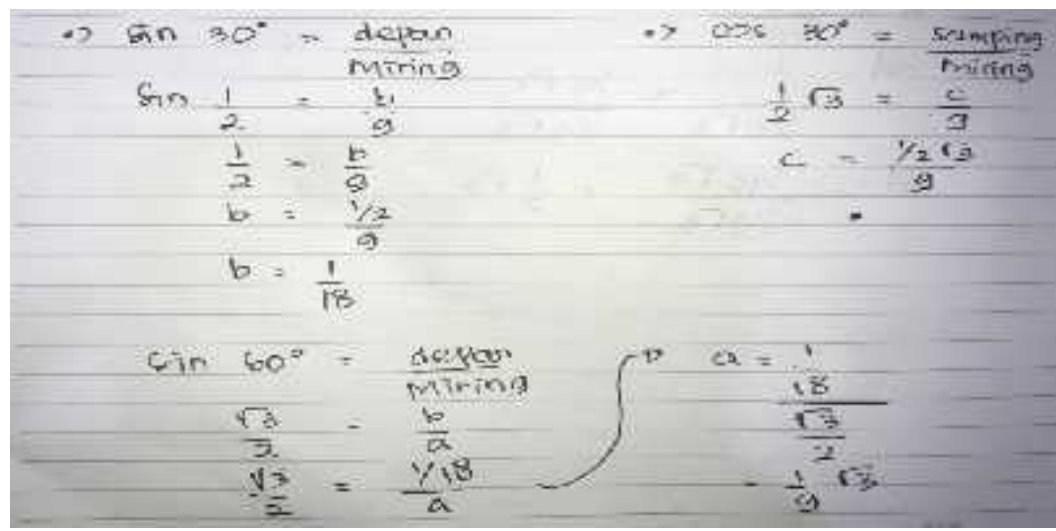

\section{Kesalahan Fakta}

Gambar 5. Kesalahan Menerapkan Konsep Kesetaraan

Kesalahan fakta dalam penelitian ini yaitu kesalahan dalam mengidentifikasi informasi yang ada dalam soal. Dari 6 mahasiswa yang mengalami kesalahan ini dipilih 1 mahasiswa yang dapat memberikan penjelasan secara detail dari jawabannya sebagai subjek kelima (S5) dalam penelitian ini. Hasil pekerjaan subjek kelima (S5) dapat dilihat dalam Gambar 6. Dari Gambar 6 dapat dilihat bahwa subjek terlebih dahulu membagi segitiga menjadi dua segitiga. Kemudian subjek menentukan nilai $a$ dan $d$ dengan menggunakan cos 60 derajat. Kesalahan subjek adalah tidak memperhatikan bahwa panjang sisi dari segitiga tersebut juga dipengaruhi oleh panjang sisi yang lainnya yaitu 9. Akibatnya subjek mengalami kesalahan dalam menyelesaikan masalah segitiga. Faktor penyebab kesalahan ini dapat diketahui dari cuplikan transkrip wawancara berikut.

$P \quad:$ Jelaskan bagaimana Anda memperoleh jawaban tersebut?

S5 : Disitu disajikan sebuah gambar dua segitiga yang saling berhimpit di garis $b$. jadinya ada segitiga di sebelah kanan dan ada segitiga di sebelah kiri. ... Saya terlebih dahulu mencari sisi-sisi yang menghimpit sudut 60 derajat, yaitu sisi d dan a, untuk mencari sisi d dan a dengan rumus cos, yaitu cosami. Jadinya untuk mencari sisi d dan a yaitu cos 60 derajat sama dengan d per a, cos 60 derajat itu 1/2 sama dengan $d$ per a, jadinya $d=1$ dan $a=2 . \ldots$

Dari cuplikan transkrip hasil wawancara dapat diketahui bahwa perhatian subjek hanya tertuju pada segitiga yang dibagi menjadi dua tanpa memperhatikan panjang sisi yang diketahui, yaitu 9. Selanjutnya subjek mencari panjang sisi-sisi yang ditanyakan dengan tidak melibatkan panjang sisi yang diketahui. Ini artinya faktor penyebab subjek mengalami kesalahan fakta dalam menyelesaikan masalah segitiga adalah perhatian subjek yang tidak secara menyeluruh terhadap informasi yang diberikan serta tidak memikirkan bahwa panjang sisi-sisi segitiga tersebut dipengaruhi oleh besar sudut dan panjang sisi yang lainnya.

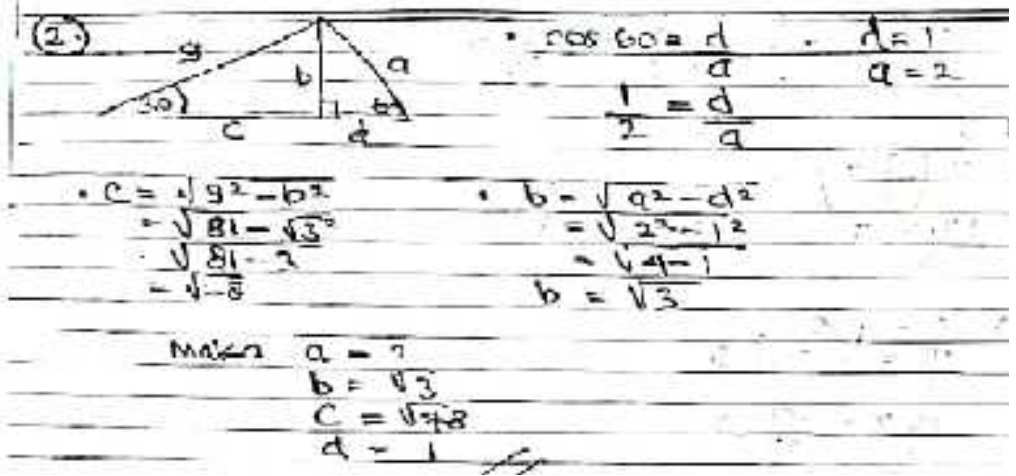

Gambar 6. Kesalahan Mengidentifikasi Informasi dalam Soal 
Dari hasil penelitian diperoleh deskripsi kesalahan mahasiswa dalam menyelesaikan masalah segitiga pada mata kuliah trigonometri beserta faktor-faktor penyebabnya dapat dilihat dalam Tabel 3.

Tabel 3. Deskripsi Kesalahan Mahasiswa Dalam Menyelesaikan Masalah Segitiga

\begin{tabular}{cl}
\hline Jenis Kesalahan & \multicolumn{1}{c}{ Deskripsi Kesalahan } \\
\hline Kesalahan Konsep & $\begin{array}{l}\text { Kesalahan konsep dalam } \\
\text { menyelesaikan masalah segitiga } \\
\text { yaitu kesalahan dalam memahami } \\
\text { perbandingan trigonometri. }\end{array}$
\end{tabular}

\begin{tabular}{ll}
\hline Kesalahan Prinsip & Kesalahan prinsip dalam \\
& menyelesaikan masalah segitiga ada \\
& dua yaitu kesalahan dalam \\
& menerapkan definisi perbandingan \\
& trigonometri pada segitiga dan \\
& kesalahan dalam menentukan nilai \\
& fungsi trigonometri.
\end{tabular}

\begin{tabular}{lll}
\hline Kesalahan Hitung & $\begin{array}{l}\text { Kesalahan hitung dalam } \\
\text { menyelesaikan masalah segitiga } \\
\text { yaitu kesalahan dalam menghitung } \\
\text { operasi bilangan yang melibatkan } \\
\text { bentuk ekuivalen. }\end{array}$ & $\begin{array}{l}\text { Faktor penyebab kesalahan hitung ini } \\
\text { yaitu kesalahpahaman dalam } \\
\text { menentukan hasil operasi yang } \\
\text { melibatkan bentuk ekuivalensi. }\end{array}$ \\
\hline Kesalahan Fakta & $\begin{array}{l}\text { Kesalahan fakta dalam } \\
\text { menyelesaikan masalah segitiga } \\
\text { adalah tidak memperhatikan } \\
\text { panjang sisi yang diketahui untuk } \\
\text { mencari panjang sisi yang } \\
\text { ditanyakan. }\end{array}$ & $\begin{array}{l}\text { Faktor penyebab kesalahan fakta ini } \\
\text { yaitu perhatian yang tidak } \\
\text { menyeluruh terhadap informasi yang } \\
\text { diberikan serta tidak memikirkan } \\
\text { bahwa panjang sisi-sisi segitiga } \\
\text { dipengaruhi oleh besar sudut dan }\end{array}$ \\
panjang sisi yang diketahui.
\end{tabular}

Hasil penelitian ini berkonstribusi pada pengembangan teori kesalahan mahasiswa dalam menyelesaikan masalah matematika, yaitu pada pemecahan masalah segitiga dalam konteks trigonometri. Hasil penelitian menunjukkan bahwa kesalahan mahasiswa dalam menyelesaikan masalah segitiga terdiri dari kesalahan konsep, kesalahan prinsip, kesalahan hitung, dan kesalahan fakta. Hasil penelitian ini sesuai dengan hasil penelitian sebelumnya yang menunjukkan bahwa mahasiswa semester pertama juga mengalami kesalahan konsep, kesalahan prinsip, kesalahan hitung, dan kesalahan fakta dalam menyelesaikan masalah trigonometri (Abidin, 2012; Hidayat \& Aripin, 2020; Imelda, 2018; Jaelani, 2017; Nabie et al., 2018; Setiawan, 2021a; Setiawan, 2021b). Akan tetapi hasil penelitian ini memperluas hasil penelitian sebelumnya dengan menjelaskan kesalahan tersebut dalam materi pemecahan masalah segitiga pada konteks trigonometri.

Kesalahan pertama adalah kesalahan konsep. Hasil penelitian ini sesuai dengan hasil penelitian sebelumnya yang menunjukkan bahwa mahasiswa semester pertama juga mengalami kesalahan konsep dalam menyelesaikan masalah trigonometri (Abidin, 2012; Hidayat \& Aripin, 2020). Akan tetapi hasil penelitian ini memperluas hasil penelitian sebelumnya dengan menjelaskan kesalahan konsep mahasiswa dalam menyelesaikan masalah segitiga. Kesalahan konsep ini muncul karena kesalahpahaman terhadap perbandingan segitiga yang melibatkan panjang sisi yang ditanya dengan panjang sisi yang diketahui. Kesalahpahamannya adalah menghilangkan panjang sisi yang diketahui. Mislanya, diketahui 
panjang sisi miring adalah 9 dan panjang sisi depan adalah $\mathrm{b}$, serta besar sudutnya adalah $30^{\circ}$. Maka dalam menentukan nilai b subjek menghilangkan 9 , yaitu $\sin 30^{\circ}=\frac{d e}{m i}=\frac{b}{9}=\frac{1}{2}$. Sehingga subjek menjawab nilai $b$ adalah $1 / 2$.

Kesalahan kedua adalah kesalahan prinsip. Hasil penelitian ini sesuai dengan hasil penelitian sebelumnya yang menunjukkan bahwa mahasiswa semester pertama mengalami kesalahan prinsip dalam menyelesaikan masalah trigonometri (Abidin, 2012). Hasil penelitian ini memperluas hasil penelitian sebelumnya dengan menunjukkan bahwa kesalahan prinsip dalam menyelesaikan masalah segitiga yaitu kesalahan dalam menerapkan definisi trigonometri segitiga dan kesalahan dalam menentukan nilai fungsi trigonometri. Penyebab kesalahan ini adalah hanya menghafal perbandingan trigonometri segitiga. Misalnya mahasiswa menghafal bahwa SINDEMI pada segitiga siku-siku adalah $\sin \theta=\frac{a}{c}$, dimana $a$ adalah sisi depan dan $c$ adalah sisi miring. Ketiga dalam konteks soal yang berbeda, mahasiswa harus menganalisis apakah $a$ merupakan sisi depan dan $c$ merupakan sisi miring. Karena dalam konteks soal yang berbeda, bisa jadi $a$ bukan sisi depan dan $c$ bukan sisi miring. Oleh karena itu, mahasiswa tidak hanya diminta untuk menghafal perbandingan trigonometri saja, tetapi juga harus memahami konsep yang ada dalam perbandingan trigonometri serta menganalisis konteks penerapan trigonometri segitiga. Seperti yang dijelaskan oleh (Nabie et al., 2018) bahwa mahasiswa hendaknya dibekali dengan pemahamn konsep dari materi-materi trigonometri.

Kesalahan ketiga adalah kesalahan hitung. Hasil penelitian ini sesuai dengan hasil penelitian sebelumnya yang juga menunjukkan bahwa mahasiswa semester pertama mengalami kesalahan hitung dalam menyelesaikan masalah trigonometri (Gür, 2009; Imelda, 2018). Hasil penelitian ini memperluas hasil penelitian sebelumnya yang menunjukkan bahwa kesalahan hitung mahasiswa dalam menyelesaikan masalah segitiga terjadi saat menyelesaikan operasi yang melibatkan kesetaraan atau ekuivalensi. Kesalahan ini disebabkan kesalahpahaman terhadap bentuk ekuivalensi. Misalnya jika diketahui $\frac{2}{3}=\frac{a}{6}$, maka kesalahpahaman subjek mengira bahwa $a=\frac{2}{3} \div 6=\frac{1}{9}$. Oleh karena itu, mahasiswa harus memahami konsep kesetaraan atau ekuivelensi bilangan.

Kesalahan keempat adalah kesalahan fakta. Hasil penelitian ini sesuai dengan hasil penelitian sebelumnya yang menunjukkan bahwa mahasiswa semester pertama juga mengalami kesalahan fakta dalam menyelesaikan masalah trigonometri (Hidayat \& Aripin, 2020; Tuna, 2013). Hasil penelitian ini memperluas hasil penelitian sebelumnya dengan menjelaskan kesalahan fakta pada materi pemecahan masalah. Kesalahan fakta pada materi pemecahan masalah segitiga yaitu tidak mengkaitkan panjang sisi yang ditanya dengan panjang sisi yang diketahui. Oleh karena itu, perlu ditekankan bahwa panjang sisi segitiga dipengaruhi oleh besar sudut dan panjang sisi yang diketahui.

Hasil penelitian ini berimplikasi pada pembelajaran materi pemecahan masalah segitiga pada mata kuliah trigonometri untuk mengurangi kesalahan-kesalahan mahasiswa. Implikasi yang pertama adalah pembelajaran untuk mengurangi kesalahan konsep dilakukan dengan memberikan pemahaman tentang konsep-konsep dasar yang digunakan untuk menyelesaikan masalah segitiga, yaitu: : (1) definisi perbandingan trigonometri pada segitiga siku-siku (yaitu SINDEMI, COSAMI, atau TANDESA), (2) aturan sin pada segitiga (yaitu 
$\frac{a}{\sin A}=\frac{b}{\sin B}=\frac{c}{\sin C}$, (3) Teorema Pythagoras, dan (4) konsep kesetaraan (yaitu jika $\frac{a}{b}=\frac{c}{d}$, maka $\left.a=\frac{c}{d} \times b\right)$. Konsep-konsep inilah yang penting untuk diberikan kepada mahasiswa dalam menyelesaikan masalah segitiga pada konteks trigonometri. Beberapa peneliti menekankan untuk memberikan pemahaman konsep dalam setiap pembelajaran matematika (Nabie et al., 2018; Setiawan, 2019; Setiawan, 2020e, 2020b; Setiawan, Purwanto, Parta, \& Sisworo, 2020b; 2020a; Suciati, Kartowagiran, Munadi, \& Sugiman, 2019; Wongapiwatkul \& Laosinchai, 2011).

Implikasi yang kedua adalah pembelajaran untuk mengurangi kesalahan prinsip dilakukan dengan membelajarkan cara-cara menggunakan konsep, teorema, aturan atau definisi yang sesuai dengan masalah segitiga. Strategi yang sesuai untuk menyelesaikan masalah segitiga yaitu: (1) jika segitiga merupakan segitiga siku-siku, maka strategi yang efektif dan efisen adalah dengan menggunakan definisi fungsi trigonometri segitiga, yaitu SINDEMI, COSAMI, atau TANDESA dan (2) jika segitiga merupakan segitiga sebarang, maka strategi yang efektif dan efisien adalah menggunakan aturan sin pada segitiga. Hasil penelitian menunjukkan bahwa siswa yang memiliki kemampuan tinggi juga memiliki fleksibiltas yang tinggi, yaitu kemampuan untuk memilih strategi yang efektif dan efisien. (Rittle-Johnson \& Star, 2007; Setiawan, 2020a, 2020f, 2020d; Star \& Rittle-Johnson, 2008).

Implikasi yang ketiga adalah pembelajaran untuk mengurangi kesalahan hitung dilakukan dengan membelajarkan konsep ekuivalensi yang melibatkan bentuk bilangan, yaitu: (1) kedua sisi dapat dikali dengan bilangan taknol yang sama atau kedua sisi dapat dibagi dengan bilangan taknol yang sama, (2) kedua sisi dapat ditambah dengan bilangan taknol yang sama atau dikurangi dengan bilangan taknol yang sama. Implikasi yang keempat adalah pembelajaran untuk mengurangi kesalahan fakta dilakukan dengan menekankan bahwa besar sudut dan panjang sisi segitiga dipengaruhi oleh besar sudut dan juga panjang sisi. Jadi ada dua hubungan yang penting untuk diketahui dalam segitiga, yaitu: (1) besar sudut salah satu segitiga ditentukan oleh besar sudut dan panjang sisi segitiga yang diketahui, dan (2) panjang sisi salah satu segitiga ditentukan oleh besar sudut dan panjang sisi segitiga yang diketahui. Dengan melakukan pembelajaran ini, maka diharapkan kesalahan hitung dan kesalahan fakta dapat dikurangi.

\section{Kesimpulan}

Dari hasil penelitian ini dapat disimpulkan bahwa kesalahan mahasiswa semester pertama dalam menyelesaikan masalah segitiga pada mata kuliah trigonometri terdiri dari kesalahan konsep, kesalahan prinsip, kesalahan hitung, dan kesalahan fakta. Kesalahan konsep ini terjadi karena kesalahpahaman terhadap perbandingan panjang sisi yang diketahui dengan panjang sisi yang ditanyakan. Kesalahan prinsip ini terjadi karena dalam menerapkan perbandingan trigonometri segitiga tidak memperhatikan sisi depan, sisi miring, dan sisi samping serta kurang teliti dalam menentukan nilai fungsi trigonometri. Kesalahan hitung ini terjadi karena kesalahpahaman dalam menentukan hasil operasi yang melibatkan bentuk ekuivalen. Kesalahan fakta terjadi karena perhatian yang tidak menyeluruh terhadap informasi yang diberikan dan tidak menghubungkan panjang sisi yang ditanyakan dengan panjang sisi yang diketahui. 


\section{Saran}

Penelitian ini hanya terbatas pada materi pemecahan masalah segitiga pada mata kuliah trigonometri, untuk itu penelitian lanjutan yang dapat dilakukan adalah dengan menganalisis kesalahan-kesalahan mahasiswa pada materi-materi yang ada dalam mata kuliah trigonometri. Hasil analisis ini akan memberikan manfaat berupa sumbangan teoritis terhadap teori kesalahan dalam menyelesaikan masalah serta memberikan sumbangan praktis terhadap pembelajaran yang dilakukan di kelas. Selain itu, berdasarkan hasil penelitian ini, direkomendasikan kepada guru maupun dosen untuk mengurangi kesalahan konsep dengan membelajarkan konsep-konsep yang berkaitan dengan pemecahan masalah segitiga (yaitu definisi fungsi trigonometri segitiga, aturan sin pada segitiga, teorema pythagoras, dan prinsip kesetaraan). Selanjutnya, untuk mengurangi kesalahan prinsip dilakukan dengan menekankan kepada mahasiswa untuk mencari cara yang dipahami dan mudah diterapkan untuk menyelesaikan masalah serta lebih teliti dalam menyelesaikan masalah. Kemudian untuk mengurangi kesalahan hitung dilakukan dengan memahamkan siswa tentang konsep ekuivalensi bilangan. Sedangkan untuk mengurangi kesalahan fakta dilakukan dengan meminta mahasiswa untuk memperhatikan semua yang diketahui serta menghubungkan informasi yang diketahui dengan yang ditanyakan. Dengan demikian, diharapkan kesalahankesalahan mahasiswa dalam menyelesaikan masalah segitiga dapat diperbaiki.

\section{Daftar Pustaka}

Abidin, Z. (2012). Analisis Kesalahan Mahasiswa Prodi Pendidikan Matematika Fakultas Tarbiyah IAIN AR-Raniry dalam Mata Kuliah Trigonometri dan Kalkulus 1. Jurnal Ilmiah DIDAKTIKA, 13(1), 183-196.

Ball, D. L. (1993). With an Eye on the Mathematical Horizon: Dilemmas of Teaching Elementary School Mathematics. The Elementary School Journal, 93(4), 373-397.

Ball, D. L., \& Friel, S. N. (1991). Implementing the "professional standards for teaching mathematics": What's all this talk about "discourse"? The Arithmetic Teacher, 39(3), 44-48. Retrieved from http://www.jstor.org/stable/41195113

Borasi, R. (1994). Capitalizing on errors as "springboards for inquiry": A teaching experiment. Journal for Research in Mathematics Education, 25(2), 166-208. Retrieved from http://www.jstor.org/stable/749507

Downing, D. (2009). Dictionary of Mathematics Terms. Barron's Educational Series, Inc. (Third Edit). New York: Barron's Educational Series, Inc. https://doi.org/10.2307/3614426

Gür, H. (2009). Trigonometry Learning. New Horizons in Education, 57(1), 67-80.

Hidayat, W., \& Aripin, U. (2020). Identifikasi Kesalahan Jawaban Mahasiswa Pada Mata Kuliah Trigonometri Berdasarkan Dimensi Pengetahuan Krathwohl. Jurnal Nasional Pendidikan Matematika, 4(1), 142-153.

Imelda. (2018). Analisis Kesulitan Mahasiswa dalam Menyelesaikan Soal Pemecahan Masalah Pada Mata Kuliah Aljabar dan Trigonometri. Journal of Mathematics Education and Science, 4(1), 49-56.

Jaelani, A. (2017). Kesalahan jawaban tes trigonometri mahasiswa pendidikan matematika semester pertama. Journal of Mathematics Education, 3(2), 1-13.

Kazemi, E. (1998). Discourse that promotes conceptual understanding. Teaching Children Mathematics, 4(7), 410-414. Retrieved from http://www.jstor.org/stable/41197003 .

Lial, M. L., Hornsby, J., Schneider, D. I., \& Daniels, C. J. (2016). Trigonometry (11th ed.). New York: Pearson. 
Nabie, M. J., Akayuure, P., Ibrahim-Bariham, U. A., \& Sofo, S. (2018). Trigonometric concepts: Pre-service teachers' perceptions and knowledge. Journal on Mathematics Education, 9(2), 169-182. https://doi.org/10.22342/jme.9.2.5261.169-182

Rittle-Johnson, B., \& Star, J. R. (2007). Does Comparing Solution Methods Facilitate Conceptual and Procedural Knowledge? An Experimental Study on Learning to Solve Equations. Journal of Educational Psychology, 99(3), 561-574. https://doi.org/10.1037/0022-0663.99.3.561

Schleppenbach, M., Flevares, L. M., \& Sims, L. M. (2007). Teachers' responses to student mistakes in chinese and u.s. mathematics classrooms. The Elementary School Journal, 108(2), 131-147.

Setiawan, Y. E. (2019). Peta Konsep dalam Pembelajaran Matematika. Lumajang: CV. AlMukmin Yes.

Setiawan, Y. E. (2020a). Analisis Kemampuan Siswa dalam Pembuktian Kesebangunan Dua Segitiga. Al-Khwarizmi: Jurnal Pendidikan Matematika Dan Ilmu Pengetahuan Alam, 8(1), 23-38. https://doi.org/http://dx.doi.org/10.24256/jpmipa.v8i1.80

Setiawan, Y. E. (2020b). Analisis Kesalahan Siswa dalam Menggeneralisasi Pola Linier. Jurnal Nasional Pendidikan Matematika, 4(2), 180-194. https://doi.org/http://dx.doi.org/10.33603/jnpm.v4i2.3386

Setiawan, Y. E. (2020c). Analisis Kesalahan Siswa dalam Menilai Kebenaran Suatu Pernyataan. Jurnal Didaktik Matematika, 7(1), 13-31. https://doi.org/10.24815/jdm.v7i1.14495

Setiawan, Y. E. (2020d). Proses Berpikir Siswa dalam Memperbaiki Kesalahan Generalisasi Pola Linier. Mosharafa: Jurnal Pendidikan Matematika, 9(3), 371-382. https://doi.org/https://doi.org/10.31980/mosharafa.v9i3.751

Setiawan, Y. E. (2020e). Sistem Pendukung Pengambilan Keputusan Rekrutmen Guru Menggunakan Logika Fuzzy Tahani. Barekeng: Jurnal Ilmu Matematika Dan Terapan, $14(2)$,

259-272. https://doi.org/https://doi.org/10.30598/barekengvol14iss2pp259-272

Setiawan, Y. E. (2020f). The Thinking Process of Students Using Trial and Error Strategies in Generalizing Linear Patterns. Numerical: Jurnal Matematika Dan Pendidikan Matematika, 4(1), 1-12. https://doi.org/https://doi.org/10.25217/numerical.v4i1.839

Setiawan, Y. E. (2021a). Analisis Kesalahan Mahasiswa Semester Pertama dalam Menentukan Nilai Fungsi Trigonometri Sudut Istimewa. Supremum Journal of Mathematics Education, 5(1), 110-121. https://doi.org/10.35706/sjme.v5i1.4531

Setiawan, Y. E. (2021b). Analisis Kesalahan Mahasiswa Semester Pertama dalam Menentukan Nilai Fungsi Trigonometri Sudut Kuadran. Jurnal Cendekia: Jurnal Pendidikan Matematika, 5(1), 321-334. https://doi.org/10.31004/cendekia.v5i1.413

Setiawan, Y. E., \& Mustangin. (2020a). Kepraktisan Model Pembelajaran IDEA (Issue, Discussion, Establish, and Apply) dalam Pembelajaran Matematika. Aksioma: Jurnal Program Studi Pendidikan Matematika, 9(3), 776-788. https://doi.org/10.24127/ajpm.v9i3.2917

Setiawan, Y. E., \& Mustangin. (2020b). Validitas Model Pembelajaran IDEA ( Issue, Discussion, Establish, and Apply) untuk Meningkatkan Pemahaman Konsep. Jurnal Penelitian Pendidikan Dan Pengajaran Matematika, 6(1), 53-60. https://doi.org/https://doi.org/10.37058/jp3m.v6i1.1432

Setiawan, Y. E., Purwanto, Parta, I. N., \& Sisworo. (2020a). Disposisi berpikir produktif mahasiswa dalam menyelesaikan masalah pola bilangan dan pola geometris. Universitas Negeri Malang. 
Setiawan, Y. E., Purwanto, Parta, I. N., \& Sisworo. (2020b). Generalization Strategy of Linear Patterns From Field-Dependent Cognitive Style. Journal on Mathematics Education, 11(1), 77-94. https://doi.org/http://doi.org/10.22342/jme.11.1.9134.77-94

Setiawan, Y. E., \& Syaifuddin. (2020). Peningkatan Kompetensi Profesionalitas Guru Melalui Pelatihan Desain Pembelajaran Peta Konsep. Jurnal Pengabdian Kepada Masyarakat, 26(3), 148-153. http://dx.doi.org/10.24114/jpkm.v26i3.16377

Star, J. R., \& Rittle-Johnson, B. (2008). Flexibility in Problem Solving: The Case of Equation Solving. Learning and Instruction, 18(2008), 565-579. https://doi.org/10.1016/j.learninstruc.2007.09.018

Suciati, Kartowagiran, B., Munadi, S., \& Sugiman. (2019). The Single-Case Research of Coastal Contextual Learning Media on the Understanding of Numbers Counting Operation Concept. International Journal of Instruction, 12(3), 681-698. https://doi.org/https://doi.org/10.29333/iji.2019.12341a

Tuna, A. (2013). A Conceptual Analysis of the Knowledge of Prospective Mathematics Teachers about Degree and Radian. Word Journal of Education, 3(4), 1-9. https://doi.org/10.5430/wje.v3n4p1

Webb, N. M., \& Mastergeorge, A. M. (2003). The development of students helping behavior and learning in peer-directed small groups. Cognition and Instruction, 21(4), 361-428. https://doi.org/10.1207/s1532690xci2104

Wongapiwatkul, P., \& Laosinchai, P. (2011). Enhancing Conceptual Understanding of Trigonometry Using Earth Geometry and The Great Circle. Australian Senior, 25(1), $54-64$. 